\title{
Comparative Study between Effect of Sleeve Gastrectomy and Mini-Gastric Bypass on Type 2 Diabetes Mellitus
}

\author{
ABD EL-RAHIM M. MAHMOUD, M.Sc.; MAGDY M. MOSTAFA, M.D. and \\ MOHAMED A. ABD EL-MAKSOUD, M.D.
}

The Department of Surgery, Faculty of Medicine, Al-Azhar University, Cairo, Egypt

\begin{abstract}
Background: Severe obesity (most often defined as a BMI $\geq 35 \mathrm{~kg} / \mathrm{m}$ with comorbid health conditions or a BMI $\geq 40$ $\mathrm{kg} / \mathrm{m}^{2}$ without such conditions) is a highly prevalent chronic disease, which leads to substantial morbidity, premature mortality, impaired quality of life and excess healthcare expenditures. Bariatric surgery leads to greater weight loss and higher remission rates of type II diabetes and greater reductions in use of anti-diabetic drugs compared with nonsurgical treatment for obesity.
\end{abstract}

Aim of Study: The aim of this study is to compare between the effect of sleeve gastrectomy and mini-gastric bypass on patients with type $2 \mathrm{DM}$ and $\mathrm{BMI} \geq 35 \mathrm{~kg} / \mathrm{m}$

Patients and Methods: A prospective comparative study which included 40 obese patients with type 2 DM (20 patients were operated for Laparoscopic Sleeve Gastrectomy (LSG) and 20 patients for Laparoscopic Mini-Gastric Bypass (LMGB), with mean age at LSG group $42.95 \pm 7.63$ with range of 31-59 years, at LMGB group was $42.9 \pm 6.17$ with range of 34-58 years.

Results: In SG cases; complete remission occurred in 11 patients with percentage of $55 \%$ and failure of remission occurred in 9 patients with percentage of $45 \%$. No cases developed partial remission in SG cases. In MGB cases; 15 developed diabetic remission with percentage of $75 \%$ (11 (55\%) patients developed complete remission, 4 (20\%) patients developed partial remission). Failure of remission occurs in 5 patients in MGB cases with percentage of $25 \%$.

Conclusion: Based on our results, LSG and LMGB are efficient operations for reducing weight in morbidly obese patients and also in diabetic control in T2DM. LMGB might be superior to LSG in \%EWL and T2DM remission after 1.5 year follow-up.

Key Words: Sleeve gastrectomy - Mini-gastric bypass - DM.

\section{Introduction}

OBESITY became an epidemic disease. Physical, psychological, and economic complications are

Correspondence to: Dr. Abd El-Rahim M. Mahmoud, E-Mail: abdelrahimmohamadin@gmail.com associated with obesity which leads to difficulty in caring of obese patients by physicians [1]. Globally, type $2 \mathrm{DM}$ spreads also in parallel to obesity as more than 171 million people are affected worldwide, causing $\sim 3$ million deaths per year [2] .

Obesity and metabolic syndrome are associated with multiple complications among them type 2 $\mathrm{DM}$, and there is a great evidence that this can be managed with bariatric surgery [3] . Patients with BMI $\geq 40 \mathrm{~kg} / \mathrm{m}^{2}$ or with BMI $\geq 35 \mathrm{~kg} / \mathrm{m}^{2}$ plus comorbid conditions are candidate for bariatric or metabolic surgery as weight loss that will happen can improve co-morbidities [4].

Insulin resistance is the main problem in metabolic syndrome that leads to type $2 \mathrm{DM}$. Decreased insulin sensitivity and impaired $\beta$-cell function are the agents in pathogenesis of type $2 \mathrm{DM}$ and insulin resistance is the link between obesity and type 2 DM. The manifestations of insulin resistance are decreased transport and metabolism of insulinstimulated glucose in adipocytes and skeletal muscle and impaired suppression of hepatic glucose output [5].

The most important factor in development of insulin resistance is presence of visceral obesity and this occurs due to secretion of certain inflammatory cytokines, such as IL-6, TNF-alpha, TGF b 1 and monocyte chemotactic protein- 1 by the resident fat macrophages. Also, increased incidence of cardiovascular diseases associated with obesity is explained by the same inflammatory cytokines [6].

Occurrence of type $2 \mathrm{DM}$ with obesity is not related to degree of obesity only, but also distribution of fat accumulation has an important role, as increased upper body fat including visceral adiposity which is explained by increased abdominal 
girth or waist-to hip ratio leads to metabolic syndrome type 2DM and cardiovascular disease [7].

In a recent systematic review and meta-analysis comparing between effect of bariatric surgery and non-surgical treatment for obesity, there is greater weight loss and higher remission rates of type 2 diabetes and greater reductions in use of antidiabetic, antihypertensive and lipid lowering drugs after bariatric surgery [8]. Bariatric surgery can also decrease diabetes-related morbidity and mortality and give diabetic patients long period of DM control [9].

Indications for bariatric surgery include a BMI of $40 \mathrm{~kg} / \mathrm{m}^{2}$ or higher, or a BMI between 35 and $40 \mathrm{~kg} / \mathrm{m}^{2}$ with at least two obesity-related comorbidities, according to National Institutes of Health guidelines. DM is the most important comorbidity that determine the risk of surgery, so bariatric surgery can be done for any obese patient with BMI $\geq 35 \mathrm{~kg} / \mathrm{m}$ with type $2 \mathrm{DM}$ who failed to lose weight with other weight-control approaches [10]

Both observational and randomized controlled trials showed that type 2 DM remission and glycemic control occurred more with metabolic surgery than with medical therapy. So bariatric surgery can be offered as a treatment option for type $2 \mathrm{DM}$ in mild obese patients as it leads to reduction of morbidity and mortality for long time [11].

Aim of study: The aim of this study is to compare between the effect of sleeve gastrectomy and mini-gastric bypass on patients with type $2 \mathrm{DM}$ and $\mathrm{BMI} \geq 35 \mathrm{~kg} / \mathrm{m}^{2}$.

\section{Patients and Methods}

A prospective comparative study which included 40 obese patients (BMI $\geq 35 \mathrm{~kg} / \mathrm{m}^{2}$ ) with type 2 DM with failure of other methods of weight loss and medical treatment [20 patients were operated for Laparoscopic Sleeve Gastrectomy (LSG) and 20 patients for Laparoscopic Mini-Gastric Bypass (LMGB)], with mean age at LSG group $42.95 \pm 7.63$ with range of 31-59 years, at LMGB group was $42.9 \pm 6.17$ with range of $34-58$ years. These patients were enrolled in a combined prospective study and had a retrospectively gathered outcome analysis at the Department of Surgery, Al-Azhar University Hospitals from March 2016 to March 2018.

Inclusion criteria: (1) Adult age groups (20-60 years old), (2) Patients with BMI $\geq 35 \mathrm{~kg} / \mathrm{m}^{2}$, (3) Patients with type 2 DM.
Exclusion criteria: (1) Patients with BMI <35 $\mathrm{kg} / \mathrm{m}^{2}$, (2) Non diabetic patients, (3) Patients with type I DM.

\section{Study strategy:}

Ethical approval was taken from Al-Azhar University Ethical Committee and written consent was taken from every patient after explanation of all details of the operation, advantages, disadvantages, diet habits after surgery, realistic expectations and with the possibility of conversion to open surgery and all the possible intra-operative, early and late post-operative complications.

All patients were admitted to general surgery department, detailed medical history was taken, and complete examination and investigations were obtained (complete blood count, blood sugar, $\mathrm{HbA} 1 \mathrm{c}$, bleeding profile, renal functions, liver functions, thyroid functions, pulmonary functions, abdomino-pelvic U/S, ECG, echocardiography and venous duplex). Operations were done laparoscopically. Patients were followed-up for 18 months post-operatively.

Intervention: Laparoscopic sleeve gastrectomy and laparoscopic mini-gastric bypass. Standardized surgical technique for each LSG and LMGB was used:

For LSG, mobilization of the gastric greater curve began $6 \mathrm{~cm}$ proximal to the pylorus, and continued to the angle of his with importance accorded to the total exposure of the left crural pillar. Gastric resection using generally five to seven vertical $60 \mathrm{~mm}$ staple cartridges over a 36 French bougie Fig. (1).

For LMGB, the gastric tube was created from the angle of the lesser curvature to the left crural pillar using generally four to five vertical $60 \mathrm{~mm}$ staple cartridges over a 36 French bougie. $200 \mathrm{~cm}$ downstream the angle of Treitz, an ante-colic termino-lateral gastrojejunostomy is performed using a posterior $45-\mathrm{mm}$ roticulator linear stapler and an anterior running suture or a continuous manual suture with an absorbable suture Fig. (2). For both procedures, absence of gastric leak was verified by introducing methylene blue through a nasogastric tube at the end of the operation. On day 2, patients routinely underwent standard upper gastrointestinal tract swallow imaging. Patients were allowed to drink if no complication was observed. Patients were usually discharged on day 3 or 4 .

Follow-up: Patients were scheduled for followup visits at 1, 3, 6, 12, 18 months. Measurements 
of blood sugar, HbA1c, body weight, BMI and medications taken for DM were done in each visit.

\section{Statistical analysis:}

Data were collected, revised, coded and entered to the statistical analysis of social science (SPSS) Version 23. The qualitative data were presented as number and percentages while quantitative data were presented as mean \pm standard deviation and ranges when the data were parametric while data with non-parametric distribution were presented as median with Inter-Quartile Range (IQR). The comparisons between two groups with qualitative data were done by using Chi-square test.

The comparison between two groups with quantitative data and parametric distribution were done by using independent $t$-test while data with nonparametric distribution were done by using MannWhitney test. The confidence interval was set to 95\% and the margin of error accepted was set to $5 \%$. $p$-value was calculated.
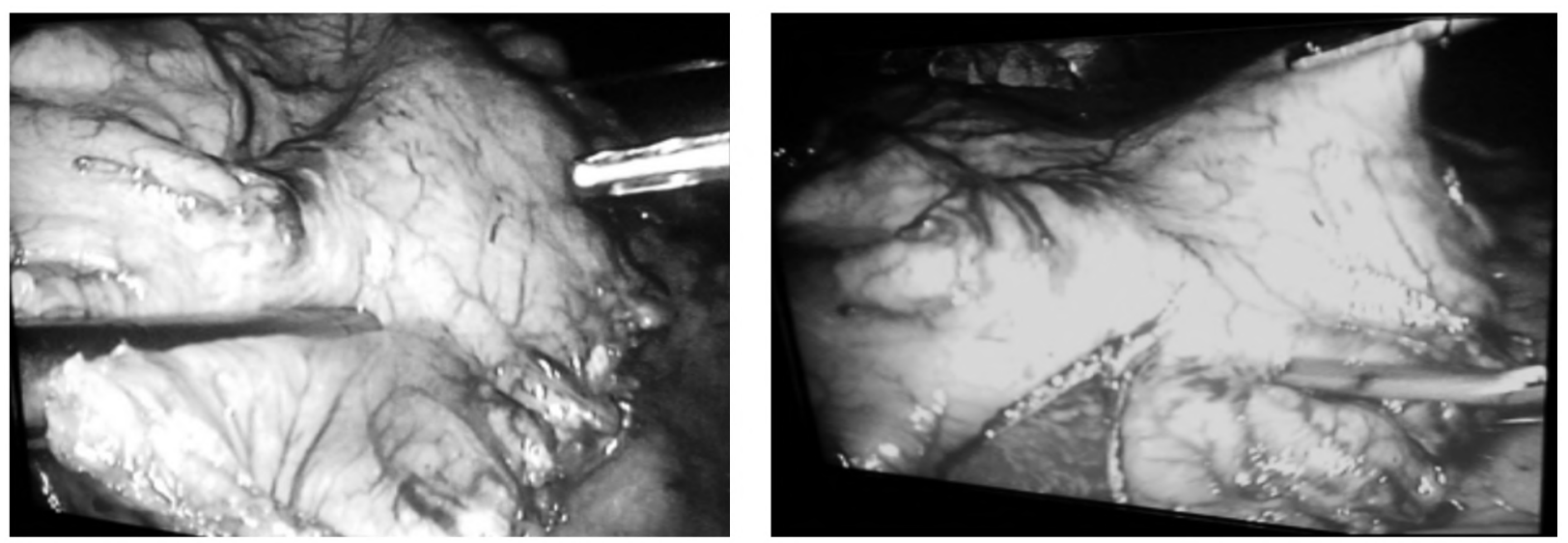

Fig. (1): Gastric resection during LSG operation.

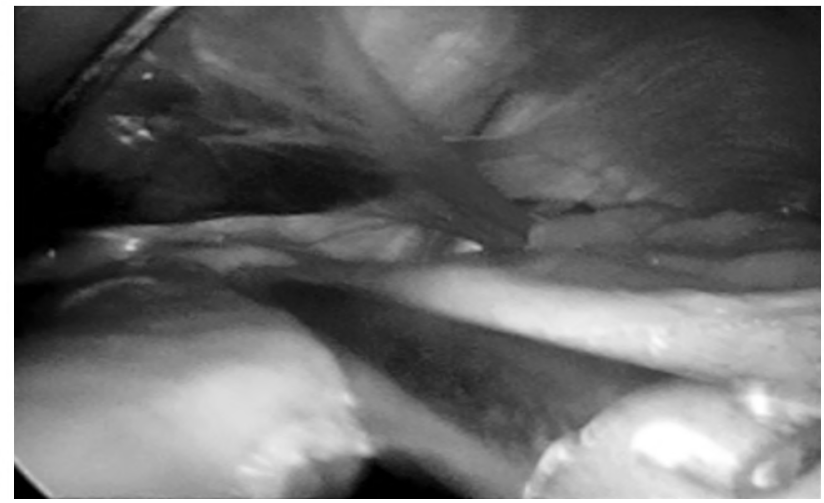

(A)

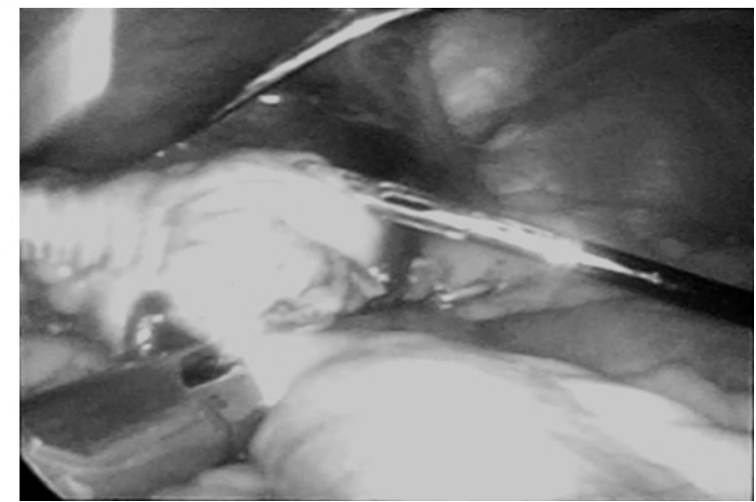

(B)

Fig. (2): (A) Gastric resection during LMGB operation. (B) Making gastro-jejunal anastomosis with stapler during LMGB.

\section{Results}

\section{Participant characteristics:}

The mean $\pm S D$ age was at $S G$ group $42.95 \pm 7.63$ with range of $31-59$ years, at MGB group was 42.9 \pm 6.17 with range of $34-58$ years. The male: female ratio was at SG group 3:17, at MGB group $7: 13$. The mean \pm SD weight of patients was at SG group $126.85 \pm 14.97$ with range of $99-164 \mathrm{Kg}$, at MGB group $134.7 \pm 11.43$ with range of $118-166 \mathrm{Kg}$. For height it was $163.1 \pm 5.87$ at $\mathrm{SG}$ group with range of $154-179 \mathrm{~cm}, 162.7 \pm 6.59$ at MGB group with range of $154-176 \mathrm{~cm}$. The mean $\pm \mathrm{SD} B M I$ was $47.77 \pm 6.18$ at $S G$ cases with range of 37.2-
$66.5\left(\mathrm{Kg} / \mathrm{m}^{2}\right), 50.88 \pm 3.99$ at MGB cases with range of 43.2-58.2 $\left(\mathrm{Kg} / \mathrm{m}^{2}\right)$. The mean $\pm \mathrm{SD}$ fasting blood sugar before operation was $114 \pm 19.66$ at SG cases with range of $81-150 \mathrm{mg} / \mathrm{dl}, 154.45 \pm 48.96$ at $\mathrm{MGB}$ cases with range of $109-258 \mathrm{mg} / \mathrm{dl}$. The mean \pm $\mathrm{SD} \mathrm{HbA1C}$ before operation was $7.5 \pm 1.06$ at $\mathrm{SG}$ cases with range of 5.2-8.9\%, $9.01 \pm 1.77$ at $\mathrm{MGB}$ cases with range of $6.7-12.7 \%$ (Table 1 ).

The duration of diabetes was different between two groups; median (IQR) was 2.5 (1-5) at SG cases with range of $0.3-7$ years, 6 (4.5-10) at MGB cases with range of $2-15$ years ( $p$-value is 0.000$)$ (Table 2). 
Pre-operative anti DM medications (insulin: Oral hypoglycemics) percentage were 9:11 (45: $55 \%)$ at SG cases, $15: 5(75: 25 \%)$ at MGB cases. The mean \pm SD duration of insulin intake was 2.5 (2-4) at SG cases with range of 1-4 years, 3 (1-4) at MGB cases with range of 0.07-6 years.

\section{Post-operative results:}

The mean \pm SD weight loss in SG cases was $45.33 \pm 5.14$ and $54.33 \pm 5.78$ after 12 and 18 months respectively, in MGB cases was $64.65 \pm 6.43$ and 76. $15 \pm 6.50$ after 12 and 18 months respectively ( $p$-value is 0.000 ). The mean $\pm \mathrm{SD}$ one year $\% \mathrm{EWL}$ was greater in MGB cases $(95.11 \pm 7.00)$ than in $\mathrm{SG}$ cases (78.48 \pm 19.07$)$ ( $p$-value is 0.001$)$ (Table 3), Fig. (3).

The degree of decrease of BMI was greater in MGB cases than SG cases during follow-up visit except after one month. Mean \pm SD degree of BMI decrease in SG cases after 12 and 18 months was $17.06 \pm 2.28$ and $20.48 \pm 2.63$ respectively; in MGB cases was $24.50 \pm 3.03$ and $28.84 \pm 2.96$ respectively, ( $p$-value is 0.000$)$ after both periods (Table 4).

When observing degree of decrease in the FBS between two groups, there was obvious difference in the whole follow-up period, in SG cases the mean \pm SD FBS decrease was $23.10 \pm 11.16$ and $24.75 \pm 12.00$ after 12 and 18 respectively while in MGB cases it was $67.40 \pm 41.20$ and $69.20 \pm 41.44$ after 12 and 18 respectively, ( $p$-value is 0.000 ) (Table 5).

As regarding the amount of decrease in the HbA1c, there was a great difference between two groups all over the follow-up period; mean \pm SDHbA1c in SG cases was $0.46 \pm 0.26,0.85 \pm 0.33$, $1.21 \pm 0.40$ and $1.50 \pm 0.53$ after 3 months, 6 months, 12 months and 18 months respectively, in MGB cases it was $1.10 \pm 0.53,2.07 \pm 0.67,2.87 \pm 0.79$ and $3.39 \pm 0.75$ after 3 months, 6 months, 12 months and 18 months respectively ( $p$-value is 0.000 ) (Table 6).

Finally, diabetic remission between two groups was as following: In SG cases; complete remission occurred in 11 patients with percentage of $55 \%$ and failure of remission occurred in 9 patients with percentage of $45 \%$. No cases developed partial remission in SG cases. In MGB cases; 15 developed diabetic remission with percentage of $75 \%$ (11 (55\%) patients developed complete remission, 4 (20\%) patients developed partial remission). Failure of remission occurs in 5 patients in MGB cases with percentage of $25 \%$ ( $p$-value is 0.185 ) (Table $7)$.
Table (1): The patient's characteristics at time of operation.

\begin{tabular}{|c|c|c|c|c|c|}
\hline & $\begin{array}{l}\text { SG cases } \\
\text { No. }=20\end{array}$ & $\begin{array}{l}\text { MGB cases } \\
\text { No. }=20\end{array}$ & $\begin{array}{l}\text { Test } \\
\text { value }\end{array}$ & $\begin{array}{c}p- \\
\text { value }\end{array}$ & 8 \\
\hline $\begin{array}{l}\text { Age (years): } \\
\text { Mean } \pm \text { SD } \\
\text { Range }\end{array}$ & $\begin{array}{l}42.95 \pm 7.63 \\
31-59\end{array}$ & $\begin{array}{l}42.9 \pm 6.17 \\
34-58\end{array}$ & $-0.023 \bullet$ & 0.982 & NS \\
\hline $\begin{array}{l}\text { Sex: } \\
\text { Females } \\
\text { Males }\end{array}$ & $\begin{array}{l}17(85.0 \%) \\
3(15.0 \%)\end{array}$ & $\begin{array}{l}13(65.0 \%) \\
7(35.0 \%)\end{array}$ & $2.133^{*}$ & 0.144 & NS \\
\hline $\begin{array}{l}W t(K g): \\
\quad \text { Mean } \pm \mathrm{SD} \\
\text { Range }\end{array}$ & $\begin{array}{l}126.85 \pm 14.97 \\
99-164\end{array}$ & $\begin{array}{l}134.7 \pm 11.43 \\
118-166\end{array}$ & $1.864 \bullet$ & 0.07 & NS \\
\hline $\begin{array}{l}H t(\mathrm{Cm}): \\
\quad \text { Mean } \pm \mathrm{SD} \\
\quad \text { Range }\end{array}$ & $\begin{array}{l}163.1 \pm 5.87 \\
154-179\end{array}$ & $\begin{array}{l}162.7 \pm 6.59 \\
154-176\end{array}$ & $-0.203 \bullet$ & 0.84 & NS \\
\hline $\begin{array}{l}B M I(K g / m 2) \\
\text { Mean } \pm \text { SD } \\
\text { Range }\end{array}$ & $\begin{array}{l}47.77 \pm 6.18 \\
37.2-66.5\end{array}$ & $\begin{array}{l}50.88 \pm 3.99 \\
43.2-58.2\end{array}$ & $1.890 \bullet$ & 0.066 & NS \\
\hline $\begin{array}{l}F B S \text { at } O D \\
(m g / d l): \\
\quad \text { Mean } \pm \text { SD } \\
\text { Range }\end{array}$ & $\begin{array}{l}114 \pm 19.66 \\
81-150\end{array}$ & $\begin{array}{l}154.45 \pm 48.96 \\
109-258\end{array}$ & 3.429 & 0.001 & HS \\
\hline $\begin{array}{l}H b A l c \text { at } O D \\
(\%): \\
\quad \text { Mean } \pm \mathrm{SD} \\
\quad \text { Range }\end{array}$ & $\begin{array}{l}7.5 \pm 1.06 \\
5.2-8.9\end{array}$ & $\begin{array}{l}9.01 \pm 1.77 \\
6.7-12.7\end{array}$ & 3.255 & 0.002 & HS \\
\hline
\end{tabular}

Table (2): Pre-operative duration of DM and anti DM medications.

\begin{tabular}{|c|c|c|c|c|c|}
\hline & $\begin{array}{l}\text { SG cases } \\
\text { No. }=20\end{array}$ & $\begin{array}{c}\text { MGB cases } \\
\text { No. }=20\end{array}$ & $\begin{array}{c}\text { Test } \\
\text { value }\end{array}$ & $\begin{array}{c}p- \\
\text { value }\end{array}$ & Sig. \\
\hline $\begin{array}{l}\text { Diabetes } \\
\text { duration } \\
\text { (years): } \\
\text { - Median } \\
\text { (IQR) } \\
\text { - Range }\end{array}$ & $\begin{array}{l}2.5(1-5) \\
0.3-7\end{array}$ & $\begin{array}{l}6(4.5-10) \\
2-15\end{array}$ & $-3.725 \bullet$ & 0.000 & HS \\
\hline $\begin{array}{l}\text { Anti DM } \\
\text { medications: } \\
\text { - Insulin } \\
\text { - Oral } \\
\text { hypoglycem } \\
\text { ics }\end{array}$ & $\begin{array}{l}9(45.0 \%) \\
11(55.0 \%)\end{array}$ & $\begin{array}{r}15(75.0 \%) \\
5(25.0 \%)\end{array}$ & $3.750 *$ & 0.053 & NS \\
\hline $\begin{array}{l}\text { Duration of } \\
\text { insulin } \\
\text { intake (years): } \\
\text { - Mean } \pm \text { SD } \\
\text { - Range }\end{array}$ & $\begin{array}{l}2.5(2-4) \\
1-4\end{array}$ & $\begin{array}{l}3(1-4) \\
0.07-6\end{array}$ & $-0.303 \bullet$ & 0.762 & NS \\
\hline $\begin{array}{ll}\text { NS } & \text { Non-Sign } \\
\text { HS } & \text { : Highly Si } \\
* & : \text { Chi-squar }\end{array}$ & $\begin{array}{l}\text { cant. } \\
\text { ificant. } \\
\text { est. }\end{array}$ & IQR & $\begin{array}{l}\text { Mann-Wh } \\
\text { Interquart }\end{array}$ & $\begin{array}{l}\text { tney tes } \\
\text { r Range }\end{array}$ & \\
\hline
\end{tabular}

Table (3): Weight loss during follow-up period in two groups.

\begin{tabular}{lccccc}
\hline $\begin{array}{l}\text { Chick } \\
\text { point }\end{array}$ & $\begin{array}{c}\text { SG cases } \\
\text { Mean } \pm \text { SD }\end{array}$ & $\begin{array}{c}\text { MGB cases } \\
\text { Mean } \pm \text { SD }\end{array}$ & $\begin{array}{c}\text { Test } \\
\text { value }\end{array}$ & $\begin{array}{c}p- \\
\text { value }\end{array}$ & Sig. \\
\hline 1 Mon & $11.65 \pm 1.90$ & $11.45 \pm 2.06$ & 0.319 & 0.751 & NS \\
3 Mon & $22.73 \pm 3.24$ & $31.35 \pm 3.53$ & -8.045 & 0.000 & HS \\
6 Mon & $33.73 \pm 4.38$ & $48.80 \pm 5.40$ & -9.693 & 0.000 & HS \\
12 Mon & $45.33 \pm 5.14$ & $64.65 \pm 6.43$ & -10.496 & 0.000 & HS \\
18 Mon & $54.33 \pm 5.78$ & $76.15 \pm 6.50$ & -11.219 & 0.000 & HS \\
\hline
\end{tabular}




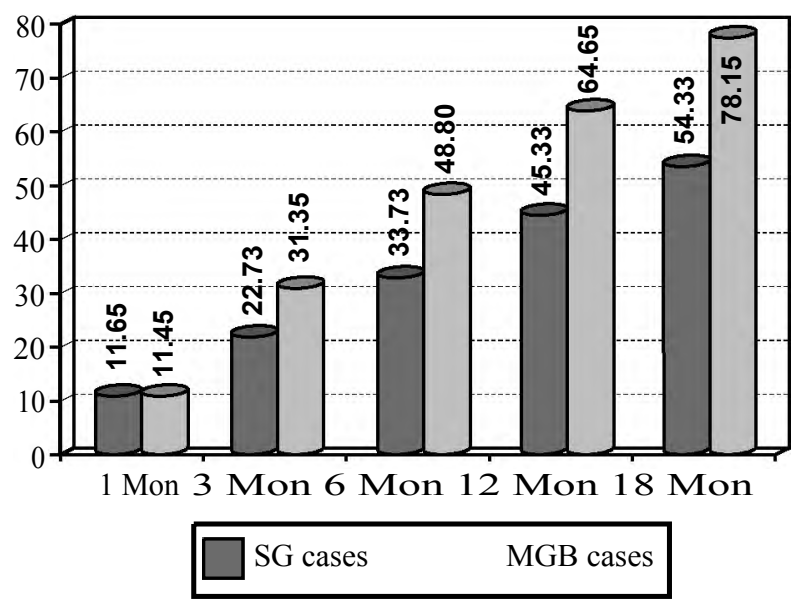

Fig. (3): Weight loss between two groups.

Table (4): BMI decrease between different follow-up visits.

\begin{tabular}{llllll}
\hline $\begin{array}{l}\text { Chick } \\
\text { point }\end{array}$ & $\begin{array}{c}\text { SG cases } \\
\text { Mean } \pm \text { SD }\end{array}$ & $\begin{array}{c}\text { MGB cases } \\
\text { Mean } \pm \text { SD }\end{array}$ & $\begin{array}{c}\text { Test } \\
\text { value }\end{array}$ & $\begin{array}{c}p \text { - } \\
\text { value }\end{array}$ & Sig. \\
\hline 1 Mon & $4.34 \pm 0.67$ & $4.33 \pm 0.89$ & 0.04 & 0.968 & NS \\
3 Mon & $8.50 \pm 1.11$ & $11.86 \pm 1.53$ & -7.949 & 0.000 & HS \\
6 Mon & $12.68 \pm 1.80$ & $18.48 \pm 2.36$ & -8.739 & 0.000 & HS \\
12 Mon & $17.06 \pm 2.28$ & $24.50 \pm 3.03$ & -8.774 & 0.000 & HS \\
18 Mon & $20.48 \pm 2.63$ & $28.84 \pm 2.96$ & -9.442 & 0.000 & HS \\
\hline
\end{tabular}

Table (5): FBS decrease between different follow-up visits.

\begin{tabular}{lccccc}
\hline $\begin{array}{l}\text { Chick } \\
\text { point }\end{array}$ & $\begin{array}{c}\text { SG cases } \\
\text { Mean } \pm \text { SD }\end{array}$ & $\begin{array}{c}\text { MGB cases } \\
\text { Mean } \pm \text { SD }\end{array}$ & $\begin{array}{c}\text { Test } \\
\text { value }\end{array}$ & $\begin{array}{c}p \text { - } \\
\text { value }\end{array}$ & Sig. \\
\hline 4 Days & $11.25 \pm 7.06$ & $32.90 \pm 26.94$ & -3.477 & 0.001 & HS \\
1 Mon & $14.78 \pm 8.64$ & $46.45 \pm 33.09$ & -4.141 & 0.000 & HS \\
3 Mon & $19.35 \pm 9.23$ & $52.40 \pm 34.03$ & -4.192 & 0.000 & HS \\
6 Mon & $22.45 \pm 10.91$ & $62.10 \pm 38.48$ & -4.433 & 0.000 & HS \\
12 Mon & $23.10 \pm 11.16$ & $67.40 \pm 41.20$ & -4.641 & 0.000 & HS \\
18 Mon & $24.75 \pm 12.00$ & $69.20 \pm 41.44$ & -4.608 & 0.000 & HS \\
\hline
\end{tabular}

Table (6): HbA1c decrease between different follow-up visits.

\begin{tabular}{lccccc}
\hline $\begin{array}{l}\text { Chick } \\
\text { point }\end{array}$ & $\begin{array}{c}\text { SG cases } \\
\text { Mean } \pm \text { SD }\end{array}$ & $\begin{array}{c}\text { MGB cases } \\
\text { Mean } \pm \text { SD }\end{array}$ & $\begin{array}{c}\text { Test } \\
\text { value }\end{array}$ & $\begin{array}{c}p \text { - } \\
\text { value }\end{array}$ & Sig. \\
\hline 3 Mon & $0.46 \pm 0.26$ & $1.10 \pm 0.53$ & -4.848 & 0.000 & HS \\
6 Mon & $0.85 \pm 0.33$ & $2.07 \pm 0.67$ & -7.305 & 0.000 & HS \\
12 Mon & $1.21 \pm 0.40$ & $2.87 \pm 0.79$ & -8.384 & 0.000 & HS \\
18 Mon & $1.50 \pm 0.53$ & $3.39 \pm 0.75$ & -9.204 & 0.000 & HS \\
\hline
\end{tabular}

Table (7): Complete and partial remission in two groups.

\begin{tabular}{|c|c|c|c|c|c|c|c|}
\hline & \multicolumn{2}{|c|}{ SG cases } & \multicolumn{2}{|c|}{ MGB cases } & \multirow{2}{*}{$\begin{array}{c}\text { Test } \\
\text { value }\end{array}$} & \multirow{2}{*}{$\begin{array}{c}p- \\
\text { value }\end{array}$} & \multirow{2}{*}{ Sig } \\
\hline & No. & $\%$ & No. & $\%$ & & & \\
\hline No & 9 & 45.0 & 5 & 25.0 & 5.143 & 0.076 & NS \\
\hline Partial & 0 & 0.0 & 4 & 20.0 & & & \\
\hline Complete & 11 & 55.0 & 11 & 55.0 & & & \\
\hline
\end{tabular}

\section{Discussion}

Nonsurgical methods achieve remission in less than $15 \%$ of treated T2DM patients which has traditionally been considered as a chronic disease [12] . According to the International Diabetes Federation (IDF) Diabetes Atlas (sixth edition), in 2013, 382 million people had diabetes worldwide and the prevalence is expected to increase to 592 million by 2035. Obesity is a strong risk factor for T2DM, and so reducing body weight is the most effective treatment for T2DM. Metabolic disease, such as T2DM can be treated by metabolic surgery, via digestive surgery, which is similar to bariatric surgery [13]

Our study is a prospective comparative study between effect of LSG and LMGB on patients with type $2 \mathrm{DM}$ and $\mathrm{BMI} \geq 35 \mathrm{~kg} / \mathrm{m}^{2}$ for short term period 1.5 year. We found that LMGB is superior on LSG on remission of T2DM and also weight loss after 1.5 year duration.

As regarding T2DM remission results; it was $75 \%$ after LMGB operation (55\% of cases expressed complete remission while partial remission occurred in $20 \%$ of cases), percentage of failed remission is $25 \%$. In LSG group, percentage of remission is $55 \%$ (all of them are complete remission), failed remission is $45 \%$ of cases. ( $p$-value was 0.076 ) which is non-significant and this is due low number of cases in the study.

Antidiabetic medication changes are different in insulin dependent patients than in patients on oral medications, as all patients on oral hypoglycemics stopped them after one year duration from operation, while in insulin dependent patients, some patients still need insulin but in low doses than before operation. But insulin doses changes are greatly different in two groups as there were more decrease post LMGB $(69.00 \pm 20.43)$ than post LSG (40.71 \pm 5.35$)$ after one year duration, ( $p$ value was 0.000 ; highly significant.

Fasting blood sugar and $\mathrm{HbA} 1 \mathrm{c}$ decreases were better in LMGB group than in LSG group in spite of preoperative measures of them were higher in LMGB group, ( $p$-value was 0.000 ; highly significant).

In our study MGB cases has greater weight loss than SG cases; ( $p$-value was 0.000 ; highly significant). $\% \mathrm{EWL}$ was greater in MGB cases than in SG cases ( $p$-value was 0.001 which is highly significant). Also BMI changes have the same results; BMI decrease is greater in MGB cases than SG 
cases during follow-up visit except after one month, ( $p$-value was 0.000$)$ after both periods.

It was noticed that improvement of diabetic control occurred in the early post-operative period especially in the MGB cases and this demonstrated that diabetic remission post bariatric surgery is not only due to weight reduction but other mechanisms are present, however great weight loss is associated with better diabetic control. Also, patients with shorter duration of DM, non-insulin dependent, small doses of insulin needed preoperatively and short duration of insulin therapy have better control of DM even if complete remission does not occur.

Our results are similar to other studies, in a double-blind randomized trial included 60 participants done by Lee and Lin [14], comparing the efficacy of diabetic control and the role of duodenal exclusion in mildly obese diabetic patients undergoing LSG and LMGB, followed-up for 5 years, it was founded that LSG and LMGB have the weight loss (LMGB; $22.8 \pm 5.9$ vs. LSG; $20.1 \pm$ $5.3 \% ; p$-value is $>0.05)$ but LMGB decreases HbA1c better than LSG (LMGB; $6.1 \pm 0.7$ vs. LSG; $7.1 \pm 1.2 \%$; $p$-value is $<0.05$ ).

In a retrospective study done by Musella et al., [15], to define the efficacy of both mini gastric bypass and sleeve gastrectomy in T2DM remission in morbidly obese patients, $63.7 \%$ of 313 patients reached one year follow-up. The mean BMI for MGB cases was $33.1 \pm 6.6$, and the mean BMI for SG cases was $35.9 \pm 5.9$ ( $p$-value is $<0.001) .85 .4 \%$ of MGB cases vs. $60.9 \%$ of SG cases were in remission ( $p$-value is $<0.001$ ). The $\%$ change vs. baseline values for HbAlc and FBS was not related to $\mathrm{BMI}$ reduction for both operations.

In a comparison of mini-gastric bypass with sleeve gastrectomy in mainly super-obese patients, Plamper et al., [16], noticed that MGB cases weight loss greater than SG cases after one year. \%EWL was $66.2 \%( \pm 13.9 \%)$ in MGB versus $57.3 \%$ $( \pm 19.0 \%)$ in SG ( $p$-value is $<0.0001)$. BMI was $34.9 \mathrm{~kg} / \mathrm{m}^{2}\left( \pm 4.8 \mathrm{~kg} / \mathrm{m}^{2}\right)$ in MGB versus $38.5 \mathrm{~kg} / \mathrm{m}^{2}$ $\left( \pm 8.6 \mathrm{~kg} / \mathrm{m}^{2}\right)$ in SG ( $p$-value is 0.001$)[16]$

A retrospective review done by Alkhalifah et al., 2018 [17], of 15-year experience of LMGB comparing it with other bariatric procedures, data showed that LMGB had great weight loss than RYGB and LSG from 2 to 6 years (LMGB: \%EWL at $1,2,5$, and 10 years were $79.0,81.1,80.4$, and 70.3\% respectively, LRYGB: \%EWL at $1,2,5$, and 10 years were $71.7,74.2,67.8$, and $66.40 \%$ respectively, LSG: \%EWL at 1, 2, 5, and 10 years were $85.2,92.2,83.7$, and $88.3 \%$ respectively). At a period of 5 years, $95.1 \% \mathrm{DM}, 87.7 \%$ dyslipidemia, $44.4 \%$ hypertension, and $76 \%$ hyperuricemia were resolved or improved. Also, it was noticed that LSG had similar high efficacy in diabetes remission rate compared to LMGB and LRYGB.

\section{Conclusion:}

Based on our results, LSG and LMGB are efficient operations for reducing weight in morbidly obese patients and also in diabetic control in T2DM. LMGB might be superior to LSG in \%EWL and T2DM remission after 1.5 year follow-up. Improvement of T2DM is not correlated to time of weight loss. Predicator of T2DM remission include duration of DM, anti-diabetic medications (oral hypoglycemics or insulin), duration of insulin taking and insulin doses needed for diabetic control limitations of this study include low number of our cases and short duration of follow-up period.

\section{References}

1- SCHROEDER R., GARRISON J.M. and JOHNSON M.S.: Treatment of Adult Obesity with Bariatric Surgery. American Family Physician, Vol. 84 (7): 806-11, 2011.

2- COHEN R., JOSE C.P., CARLOS A.S., JOÃO E.S., et al.: Effects of Gastric Bypass Surgery in Patients with Type 2 Diabetes and Only Mild Obesity. Diabetes Care, Vol. 35: 1420-8, 2012.

3- PARK H.J., HONG S., HWANG J. and HUR K.Y.: MiniGastric Bypass to Control Morbid Obesity and Diabetes Mellitus: What Radiologists Need to Know? Korean J. Radiology, Vol. 16: 325-33, 2015.

4- MANNING S., PUCCI A. and BATTERHAM R.L.: Rouxen-Y gastric bypass: Effects on feeding behaviour and underlying mechanisms, The Journal of Clinical Investigation, Vol. 125: 939-48, 2015.

5- YATURU S.: Obesity and type 2 diabetes. Journal of Diabetes Mellitus; Vol. 1: 79-95, 2011.

6- HUSSAIN A., HYDRIE M.Z., CLAUSSEN B. and ASGHAR S.: Type 2 Diabetes and obesity: A review. Journal of Diabetology, Vol. 2: 1-7, 2010.

7- ECKEL R.H., KAHEN S.E., FERRANNINI E., et al.: Obesity and Type 2 Diabetes: What Can Be Unified and What Needs to Be Individualized? Diabetes Care, Vol. 34: 1424-30, 2011.

8- GATINEAU M., HANCOCK C., HOLMAN N., et al.: Adult obesity and type 2 diabetes. Oxford: Public Health England, 211: 1-39, 2014.

9- KEIDAR A.: Bariatric Surgery for Type 2 Diabetes Reversal: The Risks. Diabetes Care, Vol. 34: 361-6, 2011.

10- KASHYAP S.R., GATMAITAN P., BRETHAUER S. and SCHAUER P.: Bariatric surgery for type 2 diabetes: Weighing the impact for obese patients. Cleveland clinic Journal of Medicine, Vol. 77: 468-76, 2010. 
11-CORDERA R. and ADAMI G.: From bariatric to metabolic surgery: Looking for a "disease modifier" surgery for type 2 diabetes, World J. Diabetes, Vol. 7: 27-33, 2016.

12- SJÖSTRÖM L., PELTONEN M., JACOBSON P., et al.: Association of bariatric surgery with long-term remission of type 2 diabetes and with microvascular and macrovascular complications. J.A.M.A., 311: 2297-304, 2014

13- NAITOH T., KASAMA K., SEKI Y., et al.: Efficacy of Sleeve Gastrectomy with Duodenal-Jejunal Bypass for the Treatment of Obese Severe Diabetes Patients in Japan: A Retrospective Multicenter Study. Obes. Surg., 2: $497-$ $505,2018$.

14-LEE W.J. and LIN Y.H.: Single-anastomosis gastric bypass (SAGB): Appraisal of clinical evidence. Obes. Surg., 24: 1749-56, 2014.
15- MUSELLA M., APERS J., RHEINWALT K., et al.: Efficacy of Bariatric Surgery in Type 2 Diabetes Mellitus Remission: The Role of Mini Gastric Bypass/One Anastomosis Gastric Bypass and Sleeve Gastrectomy at 1 Year of Follow-up, an European survey. Obes. Surg., 26: 93340, 2016.

16- PLAMPER A., LINGOHR P., NADAL J., et al.: Comparison of mini-gastric bypass with sleeve gastrectomy in a mainly super-obese patient group: First results. Surg. Endosc., 31: 1156-62, 2017.

17- ALKHALIFAH N., LEE W.J., HAI T.C., et al.: 15-year experience of laparoscopic single anastomosis (mini-) gastric bypass: Comparison with other bariatric procedures. Surgical Endoscopy, 1: 8, 2018.

\title{
دراسة مقارنة بين تآثير عملية تكمييم المعلدة

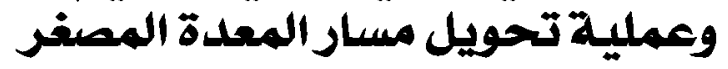 على مرض البول السكري معرى من النوع الثنانى
}

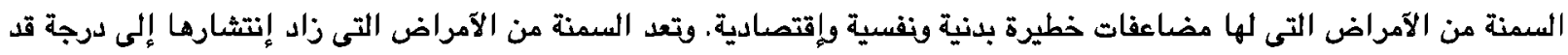

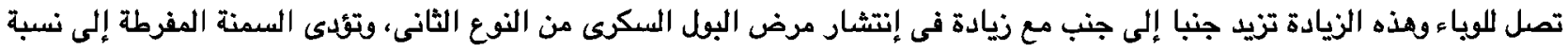

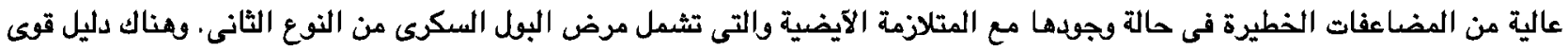

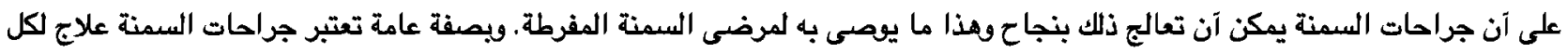

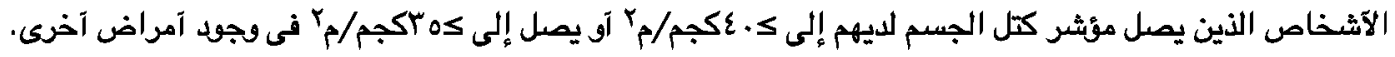

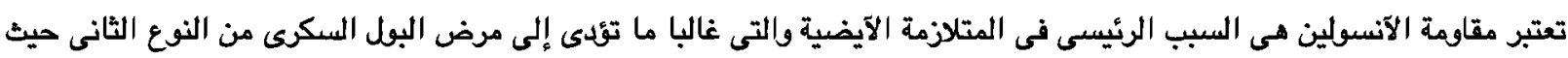

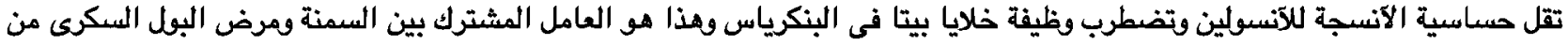

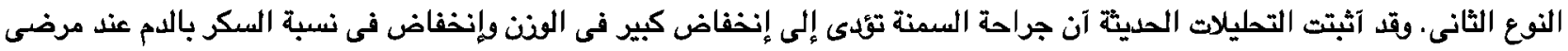

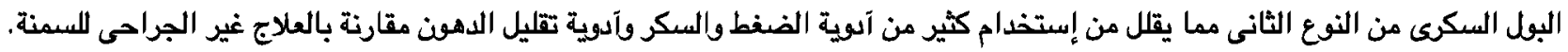 \\ وفى هذا البحث آجرينا الدراسة على .ع مريض من مرضى السمنة المفرطة مع مرض البول السكرى من النوع الثانى (آجريت عملية تكميم

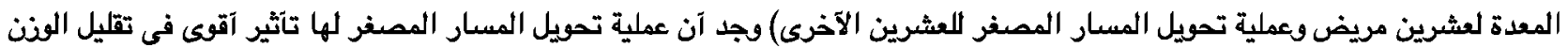

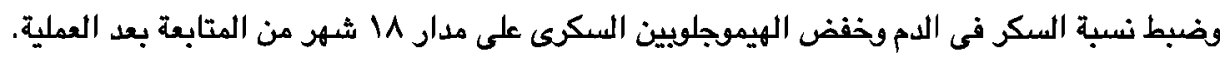

